\title{
Death as Transformation: Examining Grief Under the Perspective of the Kubler-Ross in the Selected Movies
}

\author{
Saman Salah ${ }^{1}$, Sohaila Hussain ${ }^{1}$, Ayesha Ahmed ${ }^{1}$, Abida Azam ${ }^{1} \&$ Durdana Rafique $^{1}$ \\ ${ }^{1}$ Sardar Bahadur Khan Women's University Quetta, Balochistan, Pakistan \\ Correspondence: Saman Salah, Assistant Professor, Sardar Bahadur Khan Women's University Quetta, \\ Balochistan, Pakistan. E-mail: samanmkn@gmail.com
}

Received: September 22, 2018 Accepted: October 30, 2018 Online Published: January 7, 2019

doi:10.5539/ijel.v9n1p448 URL: https://doi.org/10.5539/ijel.v9n1p448

\begin{abstract}
Death has always been a central human concern. Death is transformative; for those left, therefore, the experience of grief and loss opens another world. The meaning of grief is not simply the "Loss of ..." but the "Intense sorrow caused by the loss of a loved one (especially by death)". Grief is the price we pay for love. The deeper the love, the greater the depth of the grief that follows the loss. Grief is a shape of emotional pain; however, human beings no longer constantly trip these levels in any unique order, nor do they trip each stage. This paper draws upon the conceptual framework of Kubler-Ross five stages of grief to analyze the following movies "UP", "Baba Dook", "The Kite Runner", "Rabbit Hole", "Summer 1993" and "Three Colors: Blue" content analysis as the method of analysis. Besides, this paper explores the impact of these five stages of grief on different genders through the characters and scenes in the selected movies. This paper is an exploratory and descriptive study grounded in qualitative research design and uses content analysis as the method of analysis of the selected movies. The findings of this study show that death is a transformative phenomenon and grief unlike other emotions is a powerful tool since it raises doubt about how the grieved discovers significance throughout everyday life.
\end{abstract}

Keywords: death, grief, Kubler-Ross, genders, movies

\section{Introduction}

Grief is one of the most critical human emotions and one of the least studied. Among human emotions, the most difficult is grief to describe (Hare, 1999). It is an inspiration for writings by the world known writers from poetry to fiction. The most experienced emotion among humans is grief. Stress is considered as one of the sources of grief. Hare (1999) explains that while developing identities, relationships play a key role especially when those people are lost, and we feel as if we were lost too, uncertain of who we are and how we will keep on functioning in the world that appears to have changed unalterably. Pain is essentially the value we pay for affection. Life comes to us with the no meaning when a person experiences a loss because every memory, every act and every moment remains us of the lost. It is also noted that every person does not grieve in the same way as everyone has a different outcome for grief.

In 1969, Elizabeth Kubler-Ross published a book entitled On Death and Dying, which filled a gap in literature, practice, and education. It gave a dialect to experts and lay people to discuss loss and death, and a layout for understanding the experience. Kubler-Ross five stages of grief were (denial, anger, bargaining, depression, and acceptance) an attempt to find universal patterns in the grieving process, and it emerged from her own work with a group of terminally ill patients.

Despite that Kubler-Ross's theory had not been empirically tested, several researchers noted in 2011 that Kubler-Ross is at the time as a "guru" and that the stages presented by the theory had been generalized in both popular and professional circles to cover all kinds of grief-across individuals, cultures, and different kinds of losses (Kohler \& Konigsberg, 2011).

\subsection{Literature Review}

Death just like a grief is one of the phases of life and every person must go through it (Raphael, 2007). Grief is a stage of life while death is the end of life. Moreover, grief is the emotional response to loss and the complex amalgam of painful effects including sadness, anger, helplessness, guilt, and despair. It consists of psychological, bodily and emotional aspects (Strobe et al., 2007). The work indicates grief is spiritual due to the fact grief is a 
religious journey.

The intensity of grief is different in different age groups and in men and women (Parkes, 2002).

Kubler-Ross framework of grief comprises five stages 1) Denial 2) Anger 3) Bargaining 4) Depression 5) Acceptance which is known as "DABDA" (Kubler, 2004, p.6)

\section{1) Denial}

The first stage among grief theory is Denial. It occurs when a person experiences a loss but denies the facts.

\section{2) Anger}

The second stage is Anger where a person becomes angry after suffering from grief and thus start asking the question "Why me?" that's not good enough!; "How can this happen to me?" Who is to blame?

\section{3) Bargaining}

Among grief theory, the 3rd stage is Bargaining which includes the suffering gender commutations with God through bargaining.

\section{4) Depression}

Depression is the fourth stage in which gender totally lost, though the sadness and anger stay by side.

\section{5) Acceptance}

The last stage of grief is Acceptance where an individual eventually accepts the reality.

Kubler-Ross expressed that the stages "are not stops on some liner course of events in pain" (Kubler-Ross, 2005) every person, not experiences same or every person cannot go in a recommended arrange. Men and women are additionally a profoundly ingrained part of socialization and outing (Bandura, 1978; Bandura, 2003). Some analyst recommends gender encounter grief in an unexpected way. Female travel grief more prominent intensely while men travel sorrow in motions (Summers, Zisook, Sciolla, Patterson, Atkinson, \& Gathering, 2004).

Guinther, Segal and Bogaards (2003) found boys wind up substantially less quiet with feeling while young women meet the opposite after some period. The death toll of a parent is seen as a standout among the most irritating ways of life exercises that a youngster or immature ride (Marwitt \& Carusa, 2000). A mother in views of Moriarty, Carroll and Cotroneo (1996) feels more grief as compared to a father after the death of a child. Different investigations have watched that young men may also ride more negative mental results of parental misfortune than women (Fristad, Jedel, \& Weller, 1995; Lifshitz, 1986).

\subsection{Problem Statement}

There are many myths about death and grief that if death is not talked about; it will pass without the pain associated with the loss of a loved one. This only serves to prolong the grieving process, which can result in the stages of death not being resolved. How people grieve depends on many factors in their lives, including but not limited to the following: gender, beliefs about death, personality type, and perception of the loss. Many people think that it is not important to tell a child about death because they are too young to understand it (Wortman \& Silver, 2001). With that in mind, people never consider the fact that children lost loved ones too. Different genders and ages of people cope with grief in different ways. Grief is a conventional state of despair and grimness however it is also a life turning point in an individual's life.

Movies about death and grief can be a useful plan of action for managing our own misfortune or finding out about the misery experienced by others. Movies can be used to enlarge our vision of life and death conveys significant sentiments of fear, find comfort in a typical issue, or basically get some answers about a subject various people find hard to talk about. The stories advised by these movies allow us to comprehend, distress, and process through related experiences.

\subsection{Research Objectives}

1) To identify the five stages of grief in the selected movies.

2) To describe the impact of the different stages of grief on different genders.

3) To explore different characters of the selected movies being consoled by the stage of acceptance.

\subsection{Research Questions}

1) How stages of grief occur in the selected movies?

2) What is the impact of the different stages of grief on different genders? 
3) How the characters are being consoled by the stage of acceptance?

\section{Research Methodology}

The theoretical framework of Dr. Elizabeth Kubler-Ross is used to obtain the objectives of the study. The research design used in this study is Qualitative in nature with an exploratory and interpretative approach. The researcher uses Intrinsic and Extrinsic analysis as suggested by Wellek and Warren (1977). The intrinsic approach involves with language, character, plot, and structure and the text itself and Extrinsic approach is concerned with the contact of a text. Content analysis is used as a method of analysis since this method provides a deep understanding of the concept (Shannon, 2005). The following movies are analyzed in the paper: 1) UP 2) BabaDook 3) Kite Runner 4) Rabbit Hole 5) Summer 1993 6) Three Colors: Blue. A single movie may not always contain all the stages of grief.

\section{Analysis and Discussion}

In the movie "Up", Carl got married to his childhood friend Ellie and start a new happy life. They both decided to save their income and will visit the paradise fall which is situated in America, but time passes so quickly that they become old and Ellie become so ill and passed away and left the Carl alone. Carl denial Ellie's death and Isolated himself in his house and spend all the time reading Ellie's notes. He was also not ready to sell the house because he thinks that Ellie is living with him in that house. Ellie is still with him and in this way seven-year pass. Instead of feeling sad after Ellie he was so much angry that ones he hit the builder worker with his cane because the builder has kick Ellie's mail box, he also kicked out Ressell from his house because he thinks that Ressell wants to crush his dream and in this way, he becomes bitter day by day.

He continuously bargained with himself that if he visits paradise he would overcome from Ellie's loss or maybe he comes out from Ellie's memories. He was severely depressed and becomes ill and used a cane for walking. He also blamed himself that he didn't fulfill Ellie's last wish. One day while he was lost in his old memories he found a note from Ellie:

\section{“Thanks for the adventure-now go have a new one!" This urgent call-to-action from Ellie,"}

Then Carl decided that he would fulfill Ellie's last wish and started the journey towards the paradise fall with Ressell. At last, he found that the last blanks page which Ellie showed him before are now filled with Ellie and Carl memories. Carl realized that the real adventure was that which he and Ellie spent together. Carl accepted Ellie's death and started a new life. He found that she always wanted the Carl to stay happy and moves on his life.

As in "Babadook" Amelia's husband, Oskar dies away due to the accident that took place when he was taking her to the hospital for delivery. When she came to know that her husband had passed away she denied the death of her husband that he was no more. She thinks that the Babadook is her husband and talking with him but there was no Babadook rather, it was her own imagination and in this way, seven years passed. She was angry with her son Sam and always blamed her son for her husband's death. Sam thinks that her mother is not angry with him instead she is angry with her life and herself. One day Sam said his mother that he is hungry. She gave him shit to eat. She never allowed Sam to come near her nor she loved Sam as a child she feels so much angry that she killed the dog.

Sam bargains from his mother that

\section{“Mum I'm not leaving you. We said we'd protect each other, I know you don't love me, The Babadook won't let you, but I love you mum and I always will. You let it in, you have to get it out!"}

Sam knows that his mother was feeling very upset and missing his father that's why she hates him and not love him. He felt very hopeless when he saw other children being loved by their parents and he was not. Amelia was overwhelming depression she believes Babadook really exist and babadook was Oskar. Once she saw Babadook in her dream telling her that "Bring the child I want to kill him". Babadook was her imagination she was the one who wants to kill her son Sam because she thinks that her son is the cause of her husband's death. Sam was also depressed he thinks that Babadook was his father and he didn't allow his mother to love him and wants to kill him. At last when babadook appears she cried for the first time and says:

\section{"If you touch my son again, I'll fucking kill you!"}

She came to know that it was due to depression and grief that she blamed Sam for all the things. She accepted the death of Oskar and came out from long-lasting grief. She started caring for her son and accepted the truth that there was no Babadook. It was just her imagination. She started a new life with her son and lived happily after.

In "Summer 1993" Farida's parent was death because of Aids. At that time, she is only 6 years old. She even does not know that her parents would never come again, and she will also die due to Aids. She thinks that her parents are angry with her that's why they are gone and would come again when their anger will be over. Farida was angry with her parent why they left her alone. 


\section{“'Why aren't you crying?' a little boy asks Frida as she leaves the city.”}

But she did not answer him. In the movie we have seen that she feels that her mother is angry with her that's why she was not coming to her and not attending the call. In many scenes of the movie, we have seen that couple of time she put makeup on her face and talk in front of mirror and dress like her mother while playing with her cousin. We can imagine that how much the little Farida was depressed.

Her depressions go to peek and she decided that she will run away from her uncle house and will search for her parent. In the end, we see that tears come out from her eyes and that are tears of happiness she came out from her misery grief. She accepted her uncle and aunty as her own parent and started a new life by moving on happily and spent her remaining life living with her uncle family as a member of that family.

In "Three colors: blue" Julie was happily living with her husband Partice and young daughter Anna and one day an accident took place Partice and Anna passed away and left her alone. When she came to know about her husband and daughter death she totally denied the fact. When she was watching the funeral of her husband and daughter at that moment she was in trauma that is why she did not respond to their death even she did not cry because she did not accept the died of her loved ones. When a journalist asked a question about her husband and young daughter horrible death she completely ignored him and did not answer him. She was angry with herself that's why in the hospital she tries to jump from the window to commit suicide but at that moment nurse came and saved her life. She completely trapped herself in her house and cut down from the rest of the family and friends and started drinking coffee all the time. Julie was so much angry that she collected all the soundtrack of her husband that he composed for the upcoming United Europe celebration and she destroyed all of them.

She was so lost in grief and depression that many times she deeply dove into the swimming pool and wanted to drown herself. She left her house and sold the thing that belongs to her husband and young daughter. She tried to move from her depression, but she couldn't. The only thing she took with her to Paris was her daughter's chandelier. Whenever she sat down on the piano she used to hear the music composed by her husband but there was nobody playing the piano. Whenever she sees her daughter's chandelier, tears use to come out from her eyes that show that she had not overcome from her depression and she was helpless. When she came to know about her husband's pregnant mistress she accepted, provided shelter for her and gave the name of her husband to the unborn child

At last she gave her husband's unfinished composition to his friend to complete it and when the soundtrack of her husband was played in the United Europe celebration, she felt jovial that she fulfilled her husband's final wish and she realized that grief comes in everybody life, but the biggest thing is that to overcome from that grief and help others.

In "Rabbit hole" Howie and Becca lost their six years old child Danny. Becca completely cut down from Howie and engaged herself at home task. She wanted to escape from pain, and her mother told her to talk with her what she feels but it seems that she was angry with everyone. Becca and Howie joined the grief group she but remained silent for many months and later she leaves the group because somebody said:

\section{"God had to take her. He needed another angel."}

\section{"He needed another angel."}

\section{"Why didn't he just make one? I mean, he's God, after all. Why didn't he just make another angel?"}

It seems that Becca was bargaining with God that why her son? Why not some other children. Becca's mother wants that Becca should come out from her grief, so she told her the story of a rabbit son wants to run but rabbit mother said:

\section{“If you run away, I will run after you. For you are my little bunny".}

She feels guilty that she couldn't save her child. She told her husband that it's impossible for her to forget her son and day by day her depression increased. She throws out all the Danny clothes videos and everything that belongs to Denny. While on the other hand, Howie watched his son's old videos he wants to come out from his depression.

So, Becca decided to sell the home because she tried a lot but failed to escape from Danny memories. At last, she came to know that Danny cannot come again. By ignoring Howie, her mother Nat and her sister she was losing them. So, she came to know that how much these people are important for her as they had not left her alone when she was suffering from grief especially her loving and caring husband who helped her to overcome from Danny's grief.

In "The kite runner" Amir was shocked when he came to know that his father Baba is suffering from cancer and after some time his Baba died. Amir completely denies the death of his father and all the time he used to talk with 
his wife Soraya about Baba that how Baba and he sat on the table for breakfast and make breakfast for Baba. He thought that Baba was still with him. He received the second shock from Rahim Khan that his beloved and childhood friend Hassan was killed by Taliban in Afghanistan. And he continuously said no, no, no. He blamed himself for the death of his mother who had passed away due to pregnancy complications and he missed his mother so much that he started writing poetry for his mother. He also believes that Baba blaming him that due to him his mother was no more. He also blamed himself that he can't save the life of his friend Hassan. He continuously bargained with himself:

\section{"But how can I pack up and go back home when my actions may have caused Hassan a chance at those very same things? I wish Rahim Khan hadn't called me. I wished he had let me live on in my oblivion."}

He further decided that he will go to Kabul and saved the Hassan son. At the last scene of the movie we see that Amir, and Sohrab Hassan's son, flying the kite as after saving Sohrab, Amir takes him to America with himself and adopted him because Amir and Soraya did not have their own child. Sohrab also adopted them as his parent's and they lived happily ever after.

\section{Conclusion}

Death is an inevitable experience. After a beloved death, a person must go through grief which is unavoidable; there are no shortcuts in ways of dealing with grief. Grief is a part of life it comes in everyone's life nobody can escape from it. It depends on the person how they overcome from their grief. It varies from person to person and depends upon the person how rapidly they overcome from their grief and accept the reality and move into their lives. It depends on gender, age and the level of severity of their grief how slowly or quickly they heal from it.

Grief has implicated on children a major loss and let them to difficulty as compared to the adults. Just like parent's death can be difficult as it affects the children mentally. The death of a spouse or a partner is incredibly traumatic and might be one of the foremost devastating events in a person's life with its own specific difficulties. A person experiences more in a state of grief rather than in a happy state. The conclusions found in the study indicate that all the selected movies contain two or more than two of the five stages of grief. However, the interesting fact is that the characters going through grief in these selected movies simultaneously show "acceptance" towards their grief which gives an edge to "the stage of acceptance" as explained by Kubler Ross. Hence, it is basically the stage of acceptance which leads to the transformation of grief into something rational. This research fulfills a twofold purpose, firstly it explores Kubler- Ross's concept of grief in the selected movies. Secondly, it may help the readers to cope up with the death of a loved one by making them realize that it is obligatory for everyone to leave this world at some point; this makes them accept the fact that grief is something that everyone deals with. Hence, the study aims to provide a rational outlook of grief as a medium for transforming life.

\section{References}

Abrahams, P., Siegfried, M., \& Harris, R. (2005). Down the rabbit hole. Harper Collins.

Aubry, T. (2009). Afghanistan meets the Amazon: reading the kite runner in America. PMLA, 124(1), 25-43. https://doi.org/10.1632/pmla.2009.124.1.25

Baarsen, M. I., \& Broese van Groenou, B. (2001). Partner loss in later life: Gender differences in coping shortly after bereavement. Journal of Loss \& Trauma, 6(3), 243-262. https://doi.org/10.1080/108114401753201688

Balanzategui, J. (2017). The Babadook and the haunted space between high and low genres in the Australian horror tradition. Studies in Australasian Cinema, 11(1), 18-32. https://doi.org/10.1080/17503175.2017.1308907

Bandura, A. (1977). Self-efficacy: toward a unifying theory of behavioral change. Psychological Review, 84(2), 191. https://doi.org/10.1037/0033-295X.84.2.191

Bandura, A. (2009). Social cognitive theory of mass communication. MediaEffects, 3(3), 265-299.

Birtchnell, J. (1970). Early parent death and mental illness. The British Journal of Psychiatry, 116(532), 281-288. https://doi.org/10.1192/bjp.116.532.281

Blumberg, M. (1997). Staging AIDS: Activating Theatres. South African Theatre Journal, 11(1), 155-182. https://doi.org/10.1080/10137548.1997.9688202

Brown, K. (2005). Using motion pictures to enhance counselor effectiveness in conducting grief counseling. Doctoral dissertation, Texas Tech University.

Clewell, T. (2000). The shades of modern mourning in Three Colours trilogy. Literature/Film Quarterly, 28(3), 203. 
Coates, P. (2002). Kieślowski and the Antipolitics of Color: A Reading of the" Three Colors" Trilogy. Cinema Journal, 41-66. https://doi.org/10.1353/cj.2002.0001

Cronin Favazza, P., \& Munson, L. J. (2010). Loss and grief in young children. Young Exceptional Children, 13(2), 86-99. https://doi.org/10.1177/1096250609356883

Dempsey, A. M. (2015). The Babadook. The Irish Journal of Gothic and Horror Studies, (14), 130.

Di Ciacco, J. (2008). The colors of grief: Understanding a child's journey through loss from birth to adulthood. Jessica Kingsley Publishers.

Doka, K. J. (2014). Living with grief: After sudden loss suicide, homicide, accident, heart attack, stroke. Taylor \& Francis. https://doi.org/10.4324/9781315781563

Edwards, S., \& Buzzell, L. (2009). The waking up syndrome. Ecotherapy: Healing with nature in mind, 123-130.

Elliott, C. (2017). Social death and disenfranchised grief: An Alyawarr case study. In Mortality, mourning and mortuary practices in Indigenous Australia (pp. 125-142). Routledge.

Evely, C. (2010). 'Up': An Everyday Adventure; A Study Guide. Screen Education, (57), 62.

Fausto-Sterling, A. (2000). The five sexes revisited. The Sciences, 40(4), 18-23. https://doi.org/10.1002/j.2326-1951.2000.tb03504.x

Fenge, L. A., \& Fannin, A. (2009). Sexuality and bereavement: Implications for practice with older lesbians and gay men. Practice: Social work in action, 21(1), 35-46. https://doi.org/10.1080/09503150902745997

Fristad, M. A., Jedel, R., Weller, R. A., \& Weller, E. B. (1993). Psychosocial functioning in children after the death of a parent. The American Journal of Psychiatry, 150(3), 511. https://doi.org/10.1176/ajp.150.3.511

Fromm, E., \& Eisen, M. (1982). Self-hypnosis as a therapeutic aid in the mourning process. American Journal of Clinical Hypnosis, 25(1), 3-14. https://doi.org/10.1080/00029157.1982.10404059

Garson, P. (2005). Incredible movies: The secret identity behind children's film. Screen Education, (38), 28.

Gettig, E. (2010). Grieving: an inevitable journey. Genetic counseling practice: Advanced concepts and skills, 95-124.

Guinther, P. M., Segal, D. L., \& Bogaards, J. A. (2003). Gender differences in emotional processing among bereaved older adults. Journal of Loss \& Trauma, 8(1), 15-33. https://doi.org/10.1080/15325020305874

Halperin, E. N. (1993). Denial in the children whose parents died of AIDS. Child psychiatry and human development, 23(4), 249-257. https://doi.org/10.1007/BF00707678

Hare, R. D. (1999). Without conscience: The disturbing world of the psychopaths among us. Guilford Press.

Izod, J., \& Dovalis, J. (2014). Cinema as therapy: Grief and transformational film. Routledge. https://doi.org/10.4324/9781315731582

Kohler, N. (2011). We've been misled about how to grieve. MacLeans, 124(6), 62-63.

Kubler-Ross, E. (2009). Death: The Final Stage. Simon and Schuster.

Marwit, J., Sandra, S., \& Carusa, S. (1998). Communicated support following loss: Examining the experiences of parental death and parental divorce in adolescence. Death Studies, 22(3), 237-255. https://doi.org/10.1080/074811898201579

McDonald, A. (2011). Down the Rabbit Hole: The Madness of State Film Incentive as a Solution to Runaway Production. U. Pa. J. Bus. L., 14, 85.

Moriarty, H. J., Carroll, R., \& Cotroneo, M. (1996). Differences in bereavement reactions within couples following death of a child. Research in nursing \& health, 19(6), 461-469. https://doi.org/10.1002/(SICI)1098-240X(199612)19:6<461::AID-NUR2>3.0.CO;2-M

Parkes, C. M. (1970). "Seeking" and "finding" a lost object: Evidence from recent studies of the reaction to bereavement. Social Science \& Medicine (1967), 4(2), 187-201.

Parkes, C. M. (2002). Grief: Lessons from the past, visions for the future. Death studies, 26(5), 367-385.

Parry, G. D., Crawford, M. J., \& Duggan, C. (2016). Iatrogenic harm from psychological therapies-time to move on. The British Journal of Psychiatry, 208(3), 210-212. https://doi.org/10.1192/bjp.bp.115.163618

Peck, K. (2014). Maternal grief: A mother's heuristic inquiry. California State University, Dominguez Hills. 
Quigley, P. (2016). When Good Mothers Go Bad: Genre and Gender in The Babadook. The Irish Journal of Gothic and Horror Studies, (15), 57.

Rastegar, K. (2011). The Iranian Mediation of Afghanistan in International Art House Cinema after September 11, 2001. Globalizing Afghanistan: Terrorism, War, and the Rhetoric of Nation Building, 145.

Reyland, N. W. (2011). Zbigniew Preisner's Three Colors Trilogy: Blue, White, Red: A Film Score Guide (Vol. 11). Scarecrow Press.

Ropper, A., \& Burrell, B. D. (2014). Reaching Down the Rabbit Hole: Extraordinary Journeys into the Human Brain. Atlantic Books Ltd.

Siemienowicz, R., \& Johnston, C. (2015). Australian film industry boys club needs redressin Eureka Street, 25(23), 69.

Summers, J., Zisook, S., Sciolla, A. D., Patterson, T., \& Atkinson, J. H. (2004). Gender, AIDS, and bereavement: A comparison of women and men living with HIV. Death Studies, 28(3), 225-241. https://doi.org/10.1080/07481180490276562

Terry, A. W. (2012). My journey in grief: A mother's experience following the death of her daughter. Qualitative Inquiry, 18(4), 355-367. https://doi.org/10.1177/1077800411433549

Wortman, C. B., \& Silver, R. C. (2001). The myths of coping with loss revisited. Handbook of bereavement research: Consequences, coping, and care, 405-429. https://doi.org/10.1037/10436-017

Wozny, M. (2014). Creating an emotional impact without dialogue: the case study of Pixar's 'Up' (2009). Enquiry-The ACES Journal of Undergraduate Research, 4.

\section{Copyrights}

Copyright for this article is retained by the author, with first publication rights granted to the journal.

This is an open-access article distributed under the terms and conditions of the Creative Commons Attribution license (http://creativecommons.org/licenses/by/4.0/). 